\title{
Global Challenges of the Modern Paradigm of Economic Development
}

\author{
Natalya Gagulina ${ }^{1, *}$, Artur Budagov ${ }^{2}$, Elena Yanova $^{3}$ \\ ${ }^{1}$ Institute for Regional Economic Studies Russian Academy of Sciences Leading researcher 38, \\ Serpuhovskaya str., Saint Petersburg, 190013, Russia \\ ${ }^{2}$ State University of Aerospace Instrumentation, Director of the Institute of Enterprinership \\ Technologies, 190000, Saint Petersburg, Russia. \\ ${ }^{3}$ ITMO University, Faculty of Technological Management and Innovations, Department of Economics \\ and Strategic Management, Kronverksky avenue 49, Saint Petersburg, 197101, Russia
}

\begin{abstract}
.
Research background: The basis of the long-term sustainable movement of society forward is the paradigm of economic development as a set of scientific achievements, which for a certain period of time are recognized as the basis for the development of scientific and practical activities of the society. The paradigm of market relations is increasingly unable to solve vital problems for society and the economy, such as growing social stratification of the population, an increase in anthropogenic pollution of the biosphere, disruption of the normal functioning of ecosystems and a number of other equally important problems on a global scale.

Purpose of the article: The goal set by the authors is to conduct a study of the sustainability of the modern paradigm of economic development in the face of global challenges.

Methods: The authors carried out a systematic analysis of economic development in the face of global challenges. A new look at the relationship "global challenges - global actions" is proposed.

Findings \& Value added: The article presents the author's view on the manifestations of the crisis of the modern development paradigm, based on the correlation of global challenges and global actions.
\end{abstract}

Keywords: economic development, paradigm, global challenges, global action, quality of life.

JEL Classification: R13, F01

\footnotetext{
*Corresponding author: sovmu88@mail.ru
} 


\section{Introduction}

Comprehension of the global problems at the beginning of the third millennium prompts us to take new approach to assessing the development of modern civilization, and sometimes to question the inviolability of values formed over centuries. For more than three centuries, the development of the world's leading countries has been based on the paradigm, according to which realization of human creative potential occurs through the transformation of world and nature, and then society. Continuous growth of production and improvement of the human living standards, provided by the modern paradigm of development, are based on the ideas of progress, democracy, freedom and personal initiative. The flip side of the coin is exacerbation of key contradictions generated by the current paradigm of economic development: between wealth and poverty, liberal social practices and government guarantees, economic growth and the resource potential of nature.

\section{Economic Development Paradigm Methods}

The progressive development of mankind within the framework of accepted scientific paradigm is continuous process of improving the laws, conditions of life, social reproduction, art, science, values. One of the most important results of formation of the modern development paradigm is to recreate the world general scientific picture as an integral system of scientific ideas about nature, man and society [1]. The important role in this is played by the rapid convergence of methodology of natural science and humanitarian knowledge. Thus, the ideas of irreversibility and variability in decision-making, the variety of directions for development of complex systems at bifurcation points and many other ideas that have been developed in synergetics are becoming more and more important for the humanities.

The change in the place and role of man in the representation of most self-developing systems became manifestation of the principles of global evolutionism in the scientific paradigm of development and contributed to even greater dissemination of its ideas both in the scientific knowledge space and in the modern civilization space. The dominance of global evolutionism principles in the development paradigm has determined its influence on cultural values on the scale of the entire world economy. Besides convergence of the methodology of natural science and humanitarian knowledge, prerequisites are created for the convergence of the main, at first glance, diametrically opposed models of development of the modern East and West countries, which the main features are given in Table 1.

Table 1. Brief Description of Modern Development Models

\begin{tabular}{|l|l|l|}
\hline $\begin{array}{l}\text { Regional } \\
\text { Model Feature }\end{array}$ & Key Features & Note \\
\hline $\begin{array}{l}\text { The Modern } \\
\text { East countries }\end{array}$ & $\begin{array}{l}\text { Inseparability of property and administrative } \\
\text { power, subordination of society to the state, lack } \\
\text { of guarantees of private property and rights of } \\
\text { citizens, complete absorption of the individual by } \\
\text { the collective, economic and political domination, } \\
\text { and often a despotic state. }\end{array}$ & $\begin{array}{l}\text { There are three model } \\
\text { types: Japanese, Indian, } \\
\text { African, with their own } \\
\text { specific features. } \\
\text { China, Vietnam, North } \\
\text { Korea do not fit into the } \\
\text { listed models. }\end{array}$ \\
\hline $\begin{array}{l}\text { Western } \\
\text { countries, incl. } \\
\text { USA }\end{array}$ & $\begin{array}{l}\text { Priority of private property, policy culture, striving } \\
\text { for everything new, unconventional, pronounced } \\
\text { individualism of free personality, activity } \\
\text { transformation vector in relation to the natural and } \\
\text { social world }\end{array}$ & \\
\hline
\end{tabular}

Source: Own processing. 
Containing the human mind progress history, the modern paradigm of economic development has formed the basic laws, the laws of emergence and development of social relationships at all levels for many years to come. The manifestation of global evolutionism principles in the modern paradigm of economic development is becoming the important factor in cross-cultural interaction between East and West in connection with overarching significance of globalization, liberalization and informatization.

Globalization has become tool for formation of world markets for goods, labour and capital, has expanded the information space to planetary scale. Liberalization, pushing the boundaries of private initiative in the implementation of economic activity, stimulated investment and entrepreneurship, created conditions for the effective use of information technologies. Informatization has created new capital-intensive and rapidly growing markets for infocommunication technologies and mass media. Perhaps the most significant result of the influence of these factors in formation of the cultural space at the turn of the XX-XXI centuries was the rooting and spread of the consumer society model on global scale, closed at consumption as a way of life. First of all, this was facilitated by new opportunities for standardizing the way of life, consciousness and behaviour, education, in increasing the role of supranational structures and transnational corporations, opened under the influence of globalization.

The economy of consumer society is based on the principle of individual consumption, supported by system of attitudes and values that often ignore the laws of morality. Rapidly developing, dynamic and aggressive economy with its innovative guidelines and pronounced individualism of free personality, with active transformative vector in relation to the natural and social world, has had a huge impact on the entire social structure, starting with forms of human behaviour and social communication and ending with the rationalization of thinking in the whole [2,3]. The consumer economy does not encourage passivity and frugality, because they are accompanied by loss of consumer ability. Economic choice based on real human needs is replaced by choice dictated by the consumer society structure and the corresponding abstract values. Global scale result: overproduction and excessive consumption, accumulation of production and consumption wastes, anthropogenic pollution of atmosphere and water resources, energy overloads, etc.

The processes generated by globalization are closely related to the tightening of competition in the world market for control over natural resources and information space through the use of the latest technologies. Market relations include natural resources that were previously outside the competition [4]. The problems of preserving the natural environment and ecology associated with degradation, and sometimes destruction of the environment of human life, are ignored. Social connections and relationships are increasingly falling into the sphere of private interests. Common human values are being levelled, creating the basis of morality, humanity and social justice. The influx of cheap labour into the labour market of prosperous countries complicates interethnic relations [5,6]. The influence of psychological shock of globalization processes creates the fertile ground for nationalism outbursts.

Currently, the internationalization of all key problems is taking place against the background of globalization, liberalization and informatization: from interethnic and interconfessional conflicts to security problems $[7,8]$. This leads to the question of the crisis of the modern paradigm of economic development.

\section{Results: Economic Development Paradigm Crisis}

The modern paradigm of economic development is continuation of the general development paradigm formed by the centuries-old history of scientific discoveries and achievements. At the present stage, the great influence on the general development paradigm, generally, and 
on the economic development paradigm, particularly, was exerted by convergence of methodology of natural science and humanitarian knowledge, exchange of attitudes of the current paradigm both within the natural science segment and in the field of natural sciences and social sciences and humanities. The combined application of principles of evolutionary and systemic approaches in the paradigm of economic development not only opened up new opportunities in describing complex self-regulating and self-developing systems, the search for approaches to managing such systems, but also identified problems that called into question the viability of paradigm itself.

The aggravation of crisis situations in the economic, financial, socio-political, environmental and socio-spiritual spheres of the modern society life makes us take a new approach to understanding the modern paradigm of economic development. Achieving the better quality of life within the accepted paradigm of economic development seems to be difficult due to the problem of dominance of interests of subjects whose sources of income are non-renewable resources, harmful industries and outdated technologies. They not only stand in the way of progress, but also contribute to the emergence of such social risks as the loss of jobs, cuts in investment programs, reduction in tax payments to budgets of various levels, etc.

Regarding the complication of classical contradictions and problems of the economy, some market instruments, mechanisms, institutions become poorly managed, stochastic, and acquire a spontaneous character. The existing classical contradictions are supplemented by new ones (Figure 1).

\begin{tabular}{|l|}
\hline $\begin{array}{l}\text { contradiction between labor and capital } \\
\text { - contradictions between different capital forms } \\
\text { - contradiction between science-intensive technologies of material } \\
\text { production and archaic forms of capital reproduction } \\
\text { - contradiction in possibilities of new management approaches and } \\
\text { traditional big capital interests; } \\
\text {-problems of goods and labor balancing }\end{array}$ \\
\hline $\begin{array}{l}\text { contradictions in the model of } \\
\text { market self-regulation; }\end{array}$ \\
international law and international organizations \\
\hline
\end{tabular}

Fig. 1. Some contradictions of the economic development paradigm Source: Own processing.

Particularly, the classical contradiction between labour and capital was supplemented by contradictions between various forms of capital, rapidly developing science-intensive technologies of material production and archaic forms of capital reproduction, etc. At the international level, the contradiction between the world market globalization process and the 
national interests of the participating countries is growing [9], the crisis has emerged in the post-war system of international law and international organizations.

A series of problematic situations that have no explanation by modern science and crises that arise in vital spheres of the economy indicate a crisis of the very economic development paradigm. At the same time, problems and challenges that are urgent for all countries of the world deserve special attention.

\subsection{Global Problems and Challenges}

The term "global problems" began to be used in scientific literature in connection with concerns about population growth, environmental pollution, depletion of natural resources, etc., that is, almost simultaneously with the first models of J. Forrester, D. Meadows, and others. Understanding global problems as a set of social, natural-resource and socio-cultural problems, as the progressive development and preservation of civilization depends on the attitude towards them and which require the united efforts of all mankind for their resolution, we will group them (Figure 2). Among the problems of humanitarian nature are the problems of eliminating poverty, exploitation and other forms of social inequality, problems of education, health care, planning and regulation of the life level and quality.

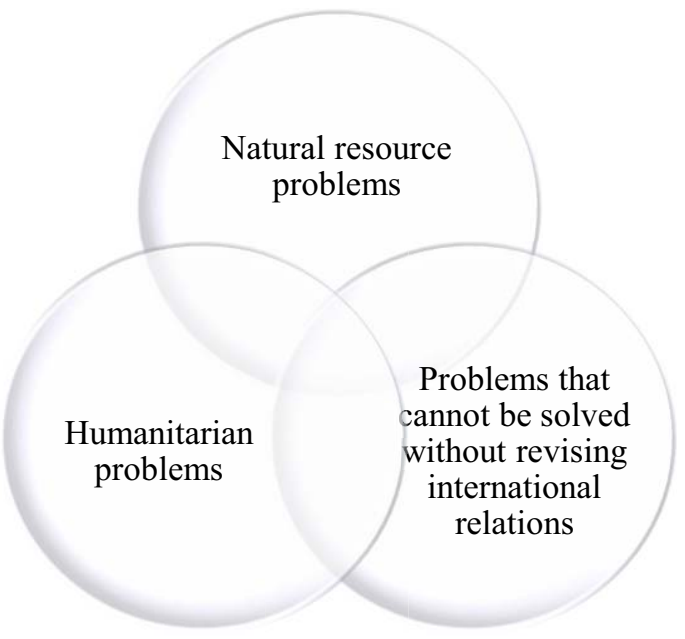

Fig. 2. Grouping of global problems

Source: Own processing.

Natural resource problems include a wide range of problems caused not only by the objective limited natural resource potential of the planet, but also by the alarmingly high rates of its use. Comparing the growth rates of the planet's population and the rate of changes in the volumes of extraction of the main types of mineral raw materials, we see that the intensity of oil and gas consumption per capita is growing (Table 2).

Table 2. Dynamics of the population and production volumes of fuel and raw materials

\begin{tabular}{|l|c|c|c|}
\hline \multirow{2}{*}{\multicolumn{1}{|c|}{ Index }} & \multicolumn{2}{c|}{ Years } & \multirow{2}{*}{ Growth index } \\
\cline { 2 - 3 } & \multicolumn{1}{|c|}{$\mathbf{1 9 5 0}$} & $\mathbf{2 0 1 1}$ & 2.8 \\
\hline Population & 2.5 billion people & 7 billion people & 8.43 \\
\hline Crude Oil & 522 million tons & 4400 million tons & 21.1 \\
\hline Gas & 190 billion $\mathrm{m}^{3}$ & 4000 billion $\mathrm{m}^{3}$ & \\
\hline
\end{tabular}


Source: [10]

Problems that cannot be solved without revising international relations owe their origin to the loss of functionality by some codes of international law and international organizations.

The close analysis of global problems, which are becoming more acute as the modern paradigm of economic development takes root, enable singling out the following ones from them:

- Climatic, ecological and biological aspects of the problem of human survival.

- The problem of preserving the individual integrity in the context of the disintegration of the traditional structures of transmission from generation to generation of such eternal global values as the value of labour, the living control of society over moral behaviour, etc. The inclusion of person simultaneously in many systems of social relations leads to personality splitting and stress.

- The problem of communicative unity of mankind and the need to resolve conflicts without the use of force. For successful dialogue focused on consent, tolerance, pluralism of opinions, new criteria and approaches are needed, and the use of double standards is unacceptable.

The exacerbation of existing or the emergence of new global problems due to failures, which is adopted the economic development paradigm as a basis, produces global challenges (Figure 3). Challenges are consequence of the emergence of new factors in world development that disrupt the stability of the normal functioning of reproduction mechanisms, intercultural relations, etc.

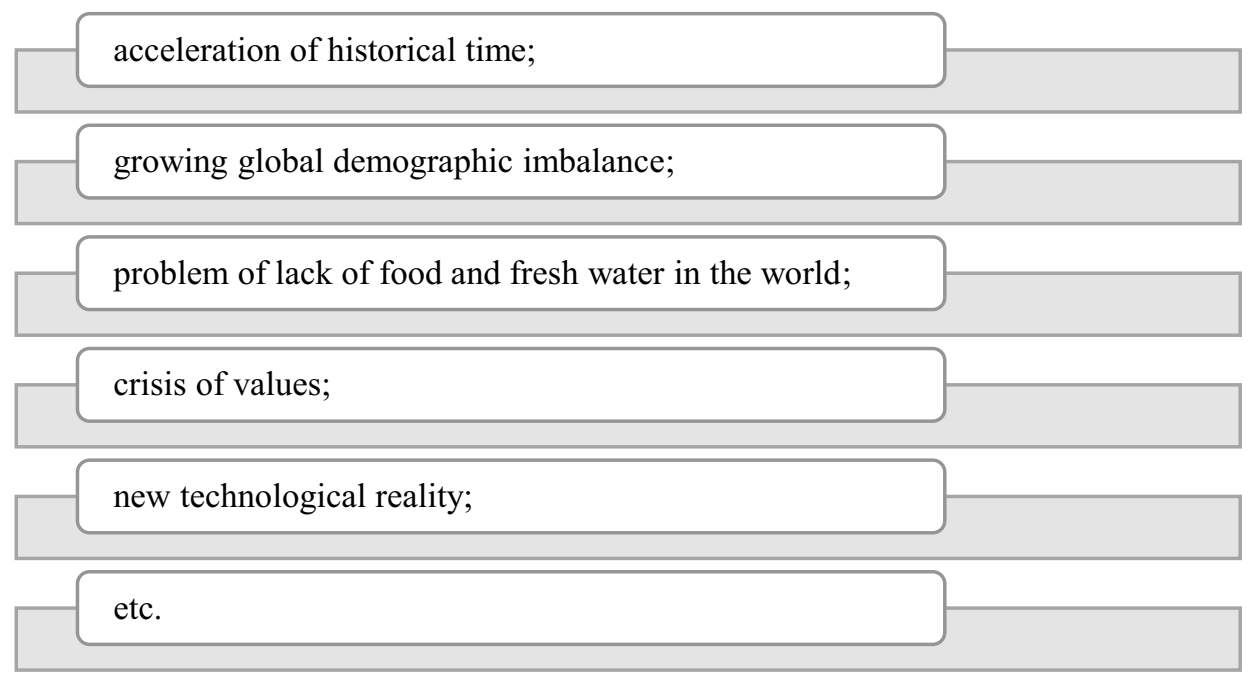

Fig. 3. Global challenges of the economic development paradigm

Source: Own processing.

Thus, the acceleration of historical time is facilitated by a constant reduction in the life cycles of goods, services, infrastructures and ways, endless and rapid change of new methods of labour and technologies in the context of accelerating the period of implementation of scientific discoveries. This complicates the adaptation of people to changes in the technological, social and cultural environment. Not having time to fully realize the benefits of change, to take advantage of them, people are faced with new, more and more technically complex aspects of life. The global demographic imbalance, which manifests itself in the population structure change, the birth rate decrease and the indigenous population decline in 
developed countries, the general aging of the world's population, including the spread of the demographic deficit to some countries in Asia and South America, contributes to the emergence of migration waves, increases economic instability. The problem of shortage of food and fresh water in the world is caused not only by the fact of limited natural resources, but also by their irrational use [11]. Economic inequality, uneven distribution of food in the world and climate change have led to the fact that more than 1 billion people in underdeveloped countries are undernourished, and between 500 million and 1 billion people go hungry. The crisis of values, provoked by the predominance of the principles of global evolutionism in the development paradigm, threatens all further development of mankind.

The problems and challenges associated with the new technological reality deserve special attention.

\subsection{Digital Economy Problems and Challenges}

The contours of new technological reality in the context of global issues have emerged due to globalization, liberalization and informatization as the leading features of the modern paradigm of economic development. The emergence of the main innovations of new technological reality in form of information and telecommunication technologies, digital communication networks and virtual reality put on different scales the advantages and disadvantages of the digital economy, selectively presented in Figure 4.

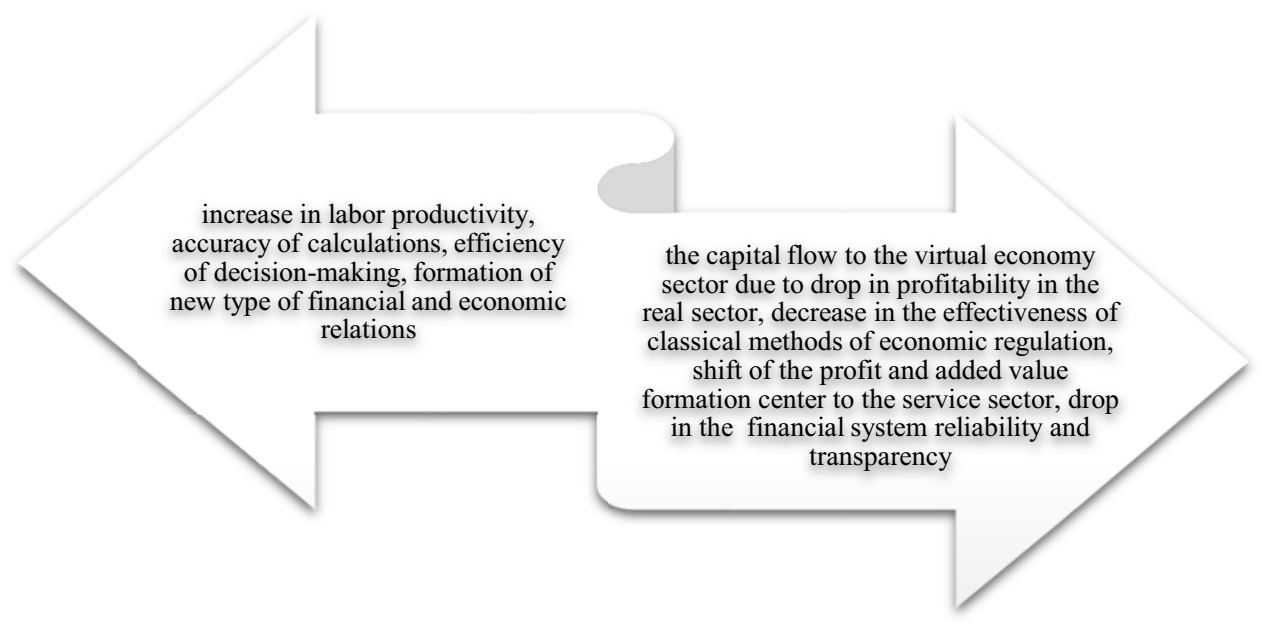

Fig. 4. Digital economy advantages and disadvantages (selective)

Source: Own processing.

Digitalization satellites on global scale are the Internet of Things and smart cities, open source public access platforms, cloud information technologies, dynamic capitalization of Internet business and info-business, increase in the volume of financial assets and the emergence of their new forms (digital assets), predictive software events providing, increasing the influence of "new media" and much more [12-14].

The formation of information space covering the whole world has become innovative form of globalization, which is accompanied by its inherent problems. In our opinion, the following can be attributed to the global challenges of the digital economy: 
a) Accelerated virtualization of the economy associated with the phenomenon of virtual reality. According to M. Poster, the problematization of reality, which so far only occurs in the field of modern telecommunications (games, teleconferences, etc.), casts doubt on the validity, exclusivity and conventional evidence of "ordinary" time, space and identity. Information superhighways and virtual reality, which have not yet become common cultural practices, have enormous potential for creating such a subject that exists only into interactive environment. Examples of large-scale transformation processes caused by many years of virtualization can be observed in the economy financial sector [15-17].

b) The spontaneous reduction of jobs in the labour market and disappearance of occupations that were widespread and in demand until recently: teachers, shop assistants, cashiers, postmen, tourism managers, notaries, call centre operators, packers, accountants, etc. The number of "useless people" includes not only the listed professions "from the risk zone", but also older age categories, which find it more difficult to adapt to innovative technological changes.

c) Computerization of the decision-making process at different levels, leading to the "cybernation" of the subject of control through the use of supercomputers. The inability of the subject of management to make adequate decisions about the most complex processes in social and technical systems in real time has led to the management crisis. Computer models, which incorporate more than a thousand mathematical equations and huge amounts of various kinds of data, enable to predict the types of behaviour of people in various situations and, in a time frame commensurate with the time for solving problems, develop ready-made solutions.

d) The gradual decrease in the ability of individuals to make decisions due to formation of stereotype to overcome the limitation of individual cognitive abilities by tools of info communication technologies.

The list of global challenges of the digital economy presented by us is very general, it can be supplemented and expanded taking into account the ongoing changes.

\section{Discussions}

Global actions in response to global challenges are foreseen in almost all spheres of human life, which are usually associated with the human welfare and well-being.

The list of global actions has more than half a century history and includes the UN Conference "Man and the Environment" (1972), the World Conservation Strategy (1980), the International Commission on Environment and Development Paper (1983), UN Conference on Environment and Development (COSR-92), Earth Summit +5 , Millennium Declaration - 2000, Earth Summit - 2002, RIO + 20, Sustainable Development Goals (SDGs), developed and adopted by the UN for the period up to 2030, and a number of other equally important international events.

It should be noted that the coordination of state policies in the field of legal regulation of information space, ecology, fight against terrorism, drug trafficking and crime also contributes to the development and implementation of global actions in response to global problems and challenges.

At the same time, it can be argued that the crisis state of the modern paradigm of economic development is accompanied by a conflict of archaic and newest forms of economic reality, which "explode" it from the inside (Figure 5). 


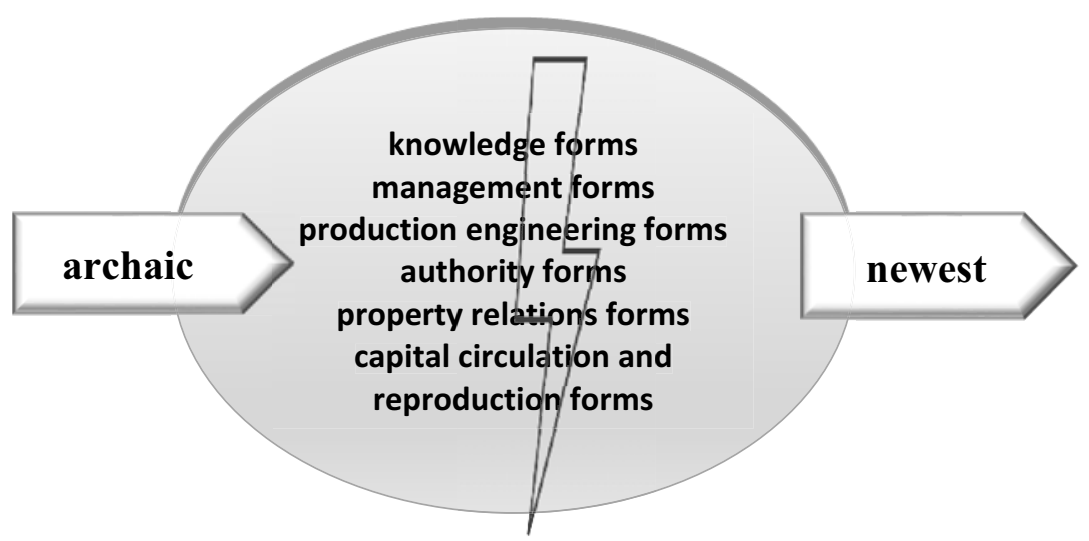

Fig. 5. Manifestations of the conflict of archaic and modern forms of economic reality Source: Own processing.

The emergence of the newest forms of economic reality in the context of the acceleration of historical time creates the risk of delay in global actions in response to global challenges. This is especially true of the challenges associated with the economic space digitalization.

\section{Conclusion}

The stability of adopted paradigm of economic development in the context of global challenges is under threat, therefore, a new look at the relationship "global challenges - global actions" is needed.

The global problems and challenges we have outlined in the modern economic development paradigm force us to start searching for a new biocompatible and biocentric paradigm aimed at harmoniously solving the problems of life support, which is accompanied by revision of views on consumption and fair distribution, attitude to the living environment and nature, life values and dominant needs. The economic development paradigm change presupposes the initial condition change for existence of socio-ecological-economic system, which will radically affect the subsequent evolution of the system and the entire organizational structure of society. In this case, it seems appropriate, in our opinion, to use the quality economics methodology, which is distinguished by interdisciplinary and comprehensive scientific approach $[18,19]$.

The economy of quality has features that make it possible to correlate it with a new, synergetic, paradigm for development of modern scientific knowledge. It is an integral part of all scientific areas, focusing on the need to take into account the quality features studied in a given aspect.

\section{References}

1. Stiopin, V. (2003) Theoretical knowledge: Structure. Moskov: Progress-Tradition.

2. Meluzin, T., Balcerzak, A.P., Pietrzak, M.B., Zinecker, M., Doubravsky, K. (2018). The impact of rumours related to political and macroeconomic uncertainty on IPO success: evidence from a qualitative model. Transformations in Business \& Economics, 17(2), 148-169. 
3. Kliestik, T.; Misankova, M.; Valaskova, K.; Svabova, L. 2018. Bankruptcy prevention: new effort to reflect on legal and social changes. Science and Engineering Ethics, 24(2), 791-803.

4. Peng MW. (2001) The resource-based view and international business. Journal of Management, 27(6), 803-829.

5. Tharenou, P., Kulik C.T. (2020). Skilled Migrants Employed in Developed, Mature Economies: From Newcomers to Organizational Insiders. Journal of Management, 46(6), 1156-1181.

6. Franklin, S., Labonne, J. (2019). Economic Shocks and Labor Market Flexibility. Journal of Human Resources, 54(1), 171-199.

7. Marano, V., Arregle, J-L., Hitt, M.A., Spadafora, E., van Essen, M. (2016). Home Country Institutions and the Internationalization-Performance Relationship: A MetaAnalytic Review. Journal of Management, 42(5), 1075-1110.

8. Gaddis, I., Pieters, J. (2016). The gendered labor market impacts of trade liberalization: evidence from Brazil. Journal of Human Resource, 52(2), 457-490.

9. Gagulina, N., Zhulega, I., Samoylov, A. (2019). Globalization and localization: The formation of the technology innovative development. In T. Kliestik (Eds.), 19th International Scientific Conference Globalization and its Socio-Economic Consequences 2019 - Sustainability in the Global-Knowledge Economy, SHS Web Conferences. Cedex: E D P Sciences.

10. Key World Energy Statistics (2011). International Energy Agency. Paris.

11. Bernstein, A., Gustafson, M. T., Lewis, R. (2019). Disaster on the horizon: The price effect of sea level rise. Journal of Financial Economics, 134(2), 253-272.

12. Sycheva, E., Budagov, A., Novikov, A. (2020). Urban infrastructure development in a global knowledge-based economy. In T. Kliestik (Eds.), 19th International Scientific Conference Globalization and its Socio-Economic Consequences 2019 - Sustainability in the Global-Knowledge Economy, SHS Web Conferences. Cedex: E D P Sciences.

13. Banalieva, E.R., Dhanaraj, Ch. (2019). Internalization theory for the digital economy. Journal of International Business Studies, 50(8), 1372-1387.

14. Kopczuk, W., Saez, E., Song, J. (2010). Earnings Inequality and Mobility in the United States: Evidence from Social Security Data Since 1937. The Quarterly Journal of Economics, 125(1), 91-128.

15. Broner, F., Ventura, J. (2016). The Effects of Financial Globalization. The Quarterly Journal of Economics, 131(3), 1497-1542.

16. Des Jardine, M., Bansal, P., Yang, Y. (2019). Bouncing Back: Building Resilience Through Social and Environmental Practices in the Context of the 2008 Global Financial Crisis. Journal of Management, 45(4), 1434-1460.

17. Heiko, J., Müller, S. (2020). Anomalies across the globe: Once public, no longer existent? Journal of Financial Economics, 135(1), 213-230.

18. Okrepilov, V., Chetyrkina, N., Krylov M. (2019). The role of elements of the economics of quality in mathematical modelling of socio-economic processes. International Scientific Conference Construction and Architecture: Theory and Practice for the Innovation Development CATPID 2019 (02008), E3S Web of Conferences.

19. Rahman, A., Belas, J., Rozsa, Z., Kliestik, T. (2017). Does ban ownership affect relationship lending: A developing country perspective. Journal of International Studies, 10(1), 277-288. 